\title{
血液透析患者におけるマキサカルシトール，静注カルシトリ オールの二次性副甲状腺機能元進症に対する効果比較
}

\author{
安藤 亮 一*1 吉川 桃乃*1 山下 裕 美*1 土肥 まゆみ*1 \\ 千田佳子*1 井田隆*1 石田雄二*2 秋葉 隆*3 \\ 中野総合病院内科*1 境南クリニック*2 \\ 東京女子医科大学腎臟病総合医療センター血液浄化部門*3
}

key words：マキサカルシトール, カルシトリオール, ビタミン D 静注製剂, 二次性副甲状腺機能六進症, whole PTH

〈要旨〉

活性型ビタミン $D$ 静注製剤である, マキサカルシトールとカルシトリオールの透析患者の二次性副甲状腺機能え 進症に対する効果を比較検討した。また，新たに開発された 1-84 副甲状腺ホルモン (PTH) のみを測定する whole PTH の測定を行い, whole PTH およびC 端の不活性フラグメント 7-84 PTH への効果についても比較検討した. 対 象は年齢, 透析歴, PTH をマッチングさせた, 各群 10 例の二次性副甲状腺機能六進症を有する透析患者である. PTH の值に応じて, マキサカルシトール 5 あるいは $10 \mu \mathrm{g}$ を週 3 回各透析後に(マキサカルシトール群), また, カルシ トリオールを 0.5 あるいは $1.0 \mu \mathrm{g}$ を週 3 回 (カルシトリオール群) より開始し, intact PTH, whole PTH, 7-84 PTH, 骨型アルカリフォスファターゼ(BAP)，インタクトオステオカルシン(iOC), | 型プロコラーゲンN プロペプチド (PINP)，補正カルシウム $(\mathrm{Ca})$ ，リン (P) に及ぼす影響について，24 週間にわたり前向きに比較検討した.

両群ともに, 4 週後に whole PTH の有意な低下が認められた. カルシトリオール群では, 8 週 12 週において PTH の低下が少ない傾向であったが, 薬剤の増量により, 16 週以後, マキサカルシトール群と同様に低下した。 Intact PTH, 7-84 PTH は, whole PTH と同様の経過を示した. BAP, iOC, PINP も同様の傾向を示したが，カルシ トリオール群では有意な低下ではなかった。 また, 補正 $\mathrm{Ca}$ は両群ともに増加, P は変動が大きいが有意な変化を認 めなかった. これらの検査値は 24 週後において, 両群間に有意な差を認めなかった. 薬剤の投与量を調節した結果, 24 週後の投与量の比は約 $7: 1$ であった。 以上より，マキサカルシトールとカルシトリオールは投与量を調節すれ ば，ほぼ同等の二次性副甲状腺機能え進症に対する効果が得られ，乥の効力比はマキサカルシトールを 1 とすると カルシトリオールで約 7 に相当すると考えられた.

\section{Prospective comparison of the effects of maxacalcitol and of intravenous calcitriol on secondary hyperparathyroidism in chronic hemodialysis patients}

Ryoichi Ando*1, Momono Yoshikawa*1, Yumi Yamashita*1, Mayumi Doi*1, Yoshiko Chida*1, Takashi Ida*1, Yuji Ishida*2, Takashi Akiba*3

Department of Medicine, Nakano General Hospital*1 ${ }^{* 1}$ Kyonan Clinic*2 ; Division of Blood Purification, Kidney Center, Tokyo Woman's Medical University*3

To compare the effect of maxacalcitol and of intravenous calcitriol on secondary hyperparathyroidism, we conducted a 24-week prospective study for 20 chronic hemodialysis patients. Five or ten $\mu \mathrm{g}$ of maxacalcitol (5 $\mu \mathrm{g}$ for patients with intact parathyroid hormone (PTH) less than $500 \mathrm{pg} / \mathrm{mL}$ and $10 \mu \mathrm{g}$ for those with intact PTH higher than $500 \mathrm{pg} / \mathrm{mL}$ ) was administered intravenously to 10 patients, and 0.5 or $1.0 \mu \mathrm{g}$ of calcitriol $(0.5$ $\mu \mathrm{g}$ for patients with intact PTH less than $500 \mathrm{pg} / \mathrm{mL}$ and $1.0 \mu \mathrm{g}$ for those with intact PTH higher than $500 \mathrm{pg} /$

安藤 亮一 中野総合病院内科 $\boldsymbol{\top}$ 164-8607 東京都中野区中央 4-59-16

Ryoichi Ando Tel : 03-3382-1231 Fax : 03-3382-1588

〔受付：平成 14 年 10 月 28 日，受理：平成 14 年 12 月 17 日〕 
$\mathrm{mL}$ ) was administered intravenously to 10 patients, at the end of every hemodialysis session. Dosage was changed according to PTH and serum calcium. We compared whole PTH, a new immunoradiometric assay exclusively for biologically active PTH (1-84), carboxy-terminal fragment (7-84) of PTH, intact PTH, bonespecific alkaline phosphatase (BAP), intact osteocalcin (iOC), amino-terminal propeptide of type I procollagen (PINP), serum calcium ajusted for albumin $(\mathrm{Ca})$ and phosphorus $(\mathrm{P})$.

Both maxacalcitol and calcitriol suppressed whole PTH 4 weeks after the start of administration. Calcitriol had less suppressing effect on whole PTH from 8 to 12 weeks of the study. From 16 to 24 weeks of the study, maxacalcitol and calcitriol showed almost equal whole PTH-suppressing effects. Intact PTH, 7-84 PTH, BAP, IOC and PINP showed almost similar changes as in whole PTH. However, the changes in BAP, IOC and PINP in patients treated with calcitriol were comparable. $\mathrm{Ca}$ increased and $\mathrm{P}$ showed no significant change. At the end of the study, there was no significant difference in these parameters between maxacalcitol and calcitriol. The effect of maxacalcitol was found to be 7 times higher than that of calcitriol.

In conclusion, maxacalcitol and calcitriol had almost equal effects on PTH, calcium and phosphorus, if dosages of these drugs are adjusted. The efficacy ratio of maxacalcitol to calcitriol was considered about 1 : 7.

\section{緒 言}

二次性副甲状腺機能㐫進症は，透析患者の主要な合 併症のひとつである. 活性型ビタミン D は直接副甲状 腺に抢ける prepro-PTH メッセンジャーRNA 産生 抑制作用, 副甲状腺細胞増殖抑制作用, ビタミン D 受 容体増加作用, 血清 $\mathrm{Ca}$ 増加作用などの機序を介して PTH の産生, 分泌を抑制する作用を有し, 本症の治療 の上で重要な役割を果たす

透析患者における二次性副甲状腺機能充進症の治療 薬として, 種々のビタミン D およびそのアナログが使 用されているが, わが国では, 従来よりもっぱら経口 剤治療がなされてきた，2000 年, わが国初めてのビ夕 ミン D アナログの注射剂であるマキサカルシトール が発売され, さらに 2001 年, 静注カルシトリオールが 2 番目の活性型ビタミン $\mathrm{D}$ 静注製剤として発売され た.これらの 2 種類の活性型ビタミン $\mathrm{D}$ 静注製剤はい ずれも, 強力な PTH 抑制作用を有し, 高度の二次性副 甲状腺機能充進症が治療対象と考元られる. 特に, マ キサカルシトールは動物実験においては, カルシトリ オールよりも血清カルシウムおよびリン上昇作用が少 なく, 同等の PTH 抑制作用があるとされるが, ヒトに おける両剤の比較に関する検討はほとんどされていな $い^{3,4)}$. 本研究では, 二次性副甲状腺機能六進症の程度, 年齢，透析歷をマッチングさせた 2 群の血液透析患者 で両剤の PTH をはじめとした種々の骨代謝マーカー に対する効果の比較検討を行った。 また, 副甲状腺機 能への効果を検討する上で, 現在広く PTH の測定に 用いられている intact PTH は本来のPTH である 1$84 \mathrm{PTH}$ 以外にその作用に拮抗するC 端フラグメン トである 7-84 PTHも一緒に測り込んでいることが
判明し，新たに開発された 1-84 PTH のみを測定する whole PTH の測定も行い, whole PTH, 7-84 PTH へ の効果についても比較検討した ${ }^{5,6)}$.

\section{I . 対象と方法}

対象は intact PTH $250 \mathrm{pg} / \mathrm{mL}$ 以上を呈する外来 血液透析患者 20 例で, 年齢, 透析歴, PTH 值が同等 になるように，10 例ずつマキサカルシトール投与群 (以下, マキサカルシトール群) と静注カルシトリオー ル投与群 (以下, カルシトリオール群) に割り当てた. 年齢はマキサカルシトール群 $54.5 \pm 13.4$ (平均土標準 偏差）（17〜 70）歳, カルシトリオール群 $53.4 \pm$ 15.0 （26～71）歳, 透析歴はマキサカルシトール群 $10.8 \pm 7.0(2.9 \sim 20.4)$ 年, カルシトリオール群 $12.1 \pm$ $6.7(3.6 \sim 25.9)$ 年でいずれも両群間に有意差を認め なかった (表).

前治療はマキサカルシトール群では 10 例中 6 例で ビタミン D 治療がなされており, うち 2 例でカルシト リオールの経ロパルス療法が行われていた。 カルシト リオール群では 10 例中 3 例でビタミン D 治療が行わ れ, うち 2 例でカルシトリオールの経ロパルス療法が 行われていた. P吸着薬は全例で処方され, マキサカル シトール群では 10 例中 9 例で沈降炭酸カルシウムが, 1 例で酢酸カルシウムが投与され, カルシトリオール 群では 10 例中 8 例で沈降炭酸カルシウムが, 酶酸カル シウム, ペリシットが各 1 例で投与されていた。沈降 炭酸カルシウムの投与量は, マキサカルシトール群で 平均 $2.8 \pm 0.8 \mathrm{~g} /$ 日, カルシトリオール群で平均 $3.1 \pm$ $0.8 \mathrm{~g} /$ 日であった. 副甲状腺のサイズはマキサカルシ トール群㧍よびカルシトリオール群いずれも 7 例にお いて超音波で計測され, 最大径はマキサカルシトール 
表 対象症例の背景

\begin{tabular}{|c|c|c|c|c|c|c|c|}
\hline 症例 & 年齢 & 性別 & $\begin{array}{c}\text { 透析歴 } \\
\text { (年) }\end{array}$ & 原疾患 & $\begin{array}{c}\text { ビタミンD } \\
\text { 前治療 }\end{array}$ & $\begin{array}{l}\text { 炭酸 Ca } \\
\text { (g/day) }\end{array}$ & $\begin{array}{c}\text { 副甲状腺腫 } \\
\text { 最大径, } \mathrm{mm}\end{array}$ \\
\hline \multicolumn{8}{|c|}{ マキサカルシトール群 } \\
\hline 1 & 70 & 女 & 3.8 & 腎硬化症 & & 1.5 & 17 \\
\hline 2 & 48 & 女 & 20.4 & CGN & 0.25 & 2 & 14 \\
\hline 3 & 17 & 男 & 2.9 & CGN & $\mathrm{OP} 2.5 / \mathrm{w}$ & 3 & 0 \\
\hline 4 & 54 & 男 & 14.7 & CGN & 0.5 & 4.5 & 12 \\
\hline 5 & 52 & 女 & 19.6 & CGN & & 3 & 17 \\
\hline 6 & 55 & 男 & 18.4 & CGN & & 3 & 11 \\
\hline 7 & 70 & 男 & 6.6 & CGN & 0.25 & 酢酸 Ca 2.9 & 11 \\
\hline 8 & 50 & 男 & 16.8 & CGN & & 3 & 測定せず \\
\hline 9 & 62 & 男 & 7.0 & CGN & 0.25 & 2 & 測定せず \\
\hline 10 & 54 & 男 & 10.5 & CGN & & 3 & 測定せず \\
\hline mean & 53.4 & & 12.1 & & & 2.8 & 11.7 \\
\hline sd & 15.0 & & 6.7 & & & 0.8 & 5.8 \\
\hline \multicolumn{8}{|c|}{ カルシトリオール群 } \\
\hline 11 & 58 & 女 & 15.0 & PCKD & & 3.5 & 9 \\
\hline 12 & 70 & 女 & 6.4 & CGN & & 1.5 & 23 \\
\hline 13 & 71 & 男 & 7.8 & CGN & & 4.5 & 測定せず \\
\hline 14 & 51 & 女 & 25.9 & CGN & $\mathrm{OP} 3.0 / \mathrm{w}$ & 3 & 6 \\
\hline 15 & 62 & 男 & 13.6 & 腎硬化症 & $\mathrm{OP} 4.0 / \mathrm{w}$ & 3 & 測定せず \\
\hline 16 & 26 & 男 & 3.6 & $\mathrm{DM}$ & & 酢酸 Ca 2.9 & 7 \\
\hline 17 & 57 & 男 & 16.7 & CGN & & 3 & 11 \\
\hline 18 & 41 & 男 & 4.9 & CGN & & 3 & 13 \\
\hline 19 & 50 & 女 & 9.1 & $\mathrm{DM}$ & & ペリシット 4 & 測定せず \\
\hline 20 & 59 & 男 & 4.9 & 腎硬化症 & 0.25 & 3 & 4 \\
\hline mean & 54.5 & & 10.8 & & & 3.1 & 10.4 \\
\hline sd & 13.4 & & 7.0 & & & 0.8 & 6.3 \\
\hline
\end{tabular}

ビタミン $\mathrm{D}$ 前治療：無印の数字は $1 \alpha$-水酸化ビタミン D の一日当たりの投与量,

$\mathrm{OP}$ は経ロパルス療法で数字は週当たりの経ロカルシトリオールの量

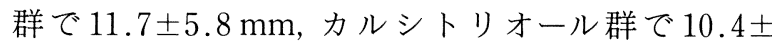
$6.3 \mathrm{~mm}$ で，両群間に差を認めなかった。

マキサカルシトールは PTH $500 \mathrm{pg} / \mathrm{mL}$ 以上で 10 $\mu \mathrm{g} \times 3 /$ 週より, PTH $500 \mathrm{pg} / \mathrm{mL}$ 未満では $5 \mu \mathrm{g} \times 3 /$ 週 より開始し， $2.5 \sim 20 \mu \mathrm{g} \times 1 \sim 3 /$ 週の範囲で調節した. また，カルシトリオールは PTH $500 \mathrm{pg} / \mathrm{mL}$ 以上は $1.0 \mu \mathrm{g} \times 3 /$ 週より PTH $500 \mathrm{pg} / \mathrm{mL}$ 未満では $0.5 \mu \mathrm{g}$ $\times 3 /$ 週より開始し, $0.5 \sim 1.5 \mu \mathrm{g} \times 1 \sim 3$ 週の範囲で調 節した.いずれも, 血清補正 Ca が $11.0 \mathrm{mg} / \mathrm{dL}$ 以上の ときは減量し, $11.5 \mathrm{mg} / \mathrm{dL}$ 以上では中止し, $11.0 \mathrm{mg} /$ dL 以下にて再開した。また，PTH の低下が不十分な 場合, 適宜增量した。

経過中, whole PTH, intact PTH，骨型アルカリ フォスファターゼ (BAP), intactオステオカルシン (iOC)， I 型プロコラーゲン N プロペプチド (PINP) を 4 週毎に，血清補正 $\mathrm{Ca} ， \mathrm{P}$ を 2 週毎に測定した。 Whole PTH は 1-6 PTH, 39-84 PTH に対する抗体 を用いた IRMA 法（Scantibodies 社）にて測定し $た^{5,6)}$. Intact PTH は IRMA 法にて，BAP は EIA 法 にて, iOC は EIA 法にて, PINP は RIA 法にて測定し
た. 7-84 PTH は, intact PTH から whole PTH をひ いて計算した。

マキサカルシトール群の 1 例が心不全により 16 週 で脱落し，カルシトリオール群の 1 例が転居により 12 週で脱落した。

透析は 1 回あたり 4 時間を週 3 回で行われ，透析液 は $\mathrm{Ca}$ 濃度 $3.0 \mathrm{mEq} / \mathrm{L}$ を使用した。

測定結果は平均值土標準誤差で示した，検定には， 対応のある，あるいは，対応のない $\mathrm{t}$ 検定を用い, $\mathrm{p}<$ 0.05 を有意差ありとした。

\section{II. 結 果}

1.PTH の経過（図 1, 2)

Whole PTH はマキサカルシトール群では投与前平 均 $289.8 \pm 49.7 \mathrm{pg} / \mathrm{mL}$ より, 4 週目で $198.4 \pm 31.9$ $\mathrm{pg} / \mathrm{mL}$ へと有意に低下した $(\mathrm{p}<0.05)$ 。その後も一部 の症例を除いて $200 \mathrm{pg} / \mathrm{mL}$ 前後で経過し， 24 週では $103.3 \pm 16.1 \mathrm{pg} / \mathrm{mL}$ と有意な低下を示した $(\mathrm{p}<$ 0.01). 16 週で上昇したが，これは一例で高 Ca 血症の 

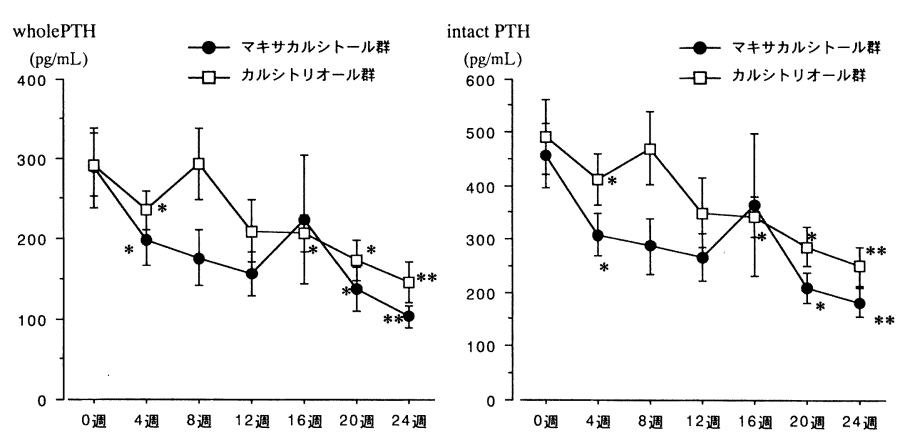

図 1 whole PTH (1-84 PTH) (左), intact PTH (1-84 PTH+7-84 PTH) (右) の経過（*p $<0.05,{ }^{* *} \mathrm{p}<0.01$ vs. 0 週)
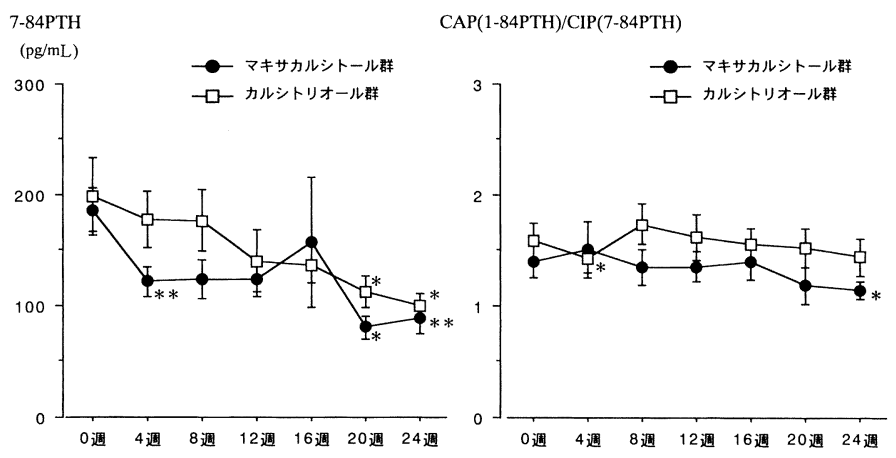

図 2 7-84 PTH (左), CAP(1-84 PTH)/CIP (7-84 PTH) 比（右）の経過 $\left({ }^{*} \mathrm{p}<0.05,{ }^{* *} \mathrm{p}<0.01\right.$ vs. 0 週 $)$

ために, 一時マキサカルシトールを中断した結果, whole PTH が $928 \mathrm{pg} / \mathrm{mL}$ まで上昇したためである. 同例はマキサカルシトールの再開にて 20 週には 72.6 $\mathrm{pg} / \mathrm{mL}$ まで低下した. カルシトリオール群では, 投与 前平均 $293.0 \pm 38.6 \mathrm{pg} / \mathrm{mL}$ より, 4 週後 $236.2 \pm 24.9$ $\mathrm{pg} / \mathrm{mL}$ と有意に低下した。 8 から 12 週ではマキサカ ルシトール群より高值傾向を示したが, 増量により 16 週以降同程度に低下し, 24 週後では, $146.0 \pm 24.5 \mathrm{pg} /$ $\mathrm{mL}$ と有意な低下を示した（ $\mathrm{p}<0.01)$ ，マキサカルシ トール群，カルシトリオール群いずれの時期において も 2 群間に有意差を認めなかった。

Intact PTH も whole PTH とほぼ同様の経過を示 し，マキサカルシトール群では投与前平均 $457.7 \pm$ $60.3 \mathrm{pg} / \mathrm{mL}$ より, 4 週目で $309.3 \pm 40.7 \mathrm{pg} / \mathrm{mL}$ へと 有意に低下した $(\mathrm{p}<0.05) .16$ 週では上昇傾向であっ たが，24 週では $182.5 \pm 28.0 \mathrm{pg} / \mathrm{mL}$ と有意な低下を 示した $(\mathrm{p}<0.01)$. Whole PTH と同様に一例は 16 週 で $1,554 \mathrm{pg} / \mathrm{mL}$ まで上昇したが，20週には $143 \mathrm{pg} /$ $\mathrm{mL}$ へ低下した. カルシトリオール群では, 投与前平均 $491.6 \pm 69.4 \mathrm{pg} / \mathrm{mL}$ より, 4 週後 $413.8 \pm 48.0 \mathrm{pg} / \mathrm{mL}$ と有意に低下し $(\mathrm{p}<0.05), 8 \sim 12$ 週では低下の程度が マキサカルシトール群に比して少なく, 16 週以降同程 度に低下し, 24 週後では, $249.4 \pm 35.9 \mathrm{pg} / \mathrm{mL}$ と有意 な低下を示した（p<0.01）。マキサカルシトール群, カルシトリオール群の間では, 8 週目でマキサカルシ トール群で $287.6 \pm 52.4 \mathrm{pg} / \mathrm{mL}$, カルシトリオール群 で $470.9 \pm 68.8 \mathrm{pg} / \mathrm{mL}$ とマキサカルシトール群でカ ルシトリオール群より有意な低值 $(\mathrm{p}<0.05)$ を示した 以外，いずれの時期においても 2 群間に有意差を認め なかった。

7-84 PTH， およびCAP (1-84 PTH)/CIP (7-84 PTH) 比の経過を図 2 に示す。7-84 PTH はマキサカ ルシトール群では, 前值 $186.3 \pm 20.3 \mathrm{pg} / \mathrm{mL}$ より, 4 週 $121.7 \pm 13.9 \mathrm{pg} / \mathrm{mL} \quad(\mathrm{p}<0.01), 20$ 週 $80.3 \pm 10.9$ $\mathrm{pg} / \mathrm{mL}(\mathrm{p}<0.05), 24$ 週 $89.2 \pm 15.0 \mathrm{pg} / \mathrm{mL}(\mathrm{p}<0.01)$ へと有意な低下を認めた。 カルシトリオール群では, 前值 $198.6 \mathrm{pg} / \mathrm{mL}$ より, 20 週 $113.2 \pm 14.1 \mathrm{pg} / \mathrm{mL}$ $(\mathrm{p}<0.05), 24$ 週 $100.6 \pm 11.1 \mathrm{pg} / \mathrm{mL}(\mathrm{p}<0.05)$ へと 有意な低下を認めた。いずれの時期においても 2 群間 には有意な差を認めなかった. CAP (1-84 PTH)/CIP (7-84 PTH) 比は, マキサカルシトール群では, 前值 $1.40 \pm 0.14$ より, 24 週 $1.14 \pm 0.08(\mathrm{p}<0.05)$ 八, 力 ルシトリオール群では, 前值 $1.59 \pm 0.16 よ り, 4$ 週 $1.43 \pm 0.12(\mathrm{p}<0.05)$ へと有意な低下を認めたが，そ の低下はわずかであり，他の時期では有意な変動を認 めなかった。いずれの時期においても 2 群間には有意 


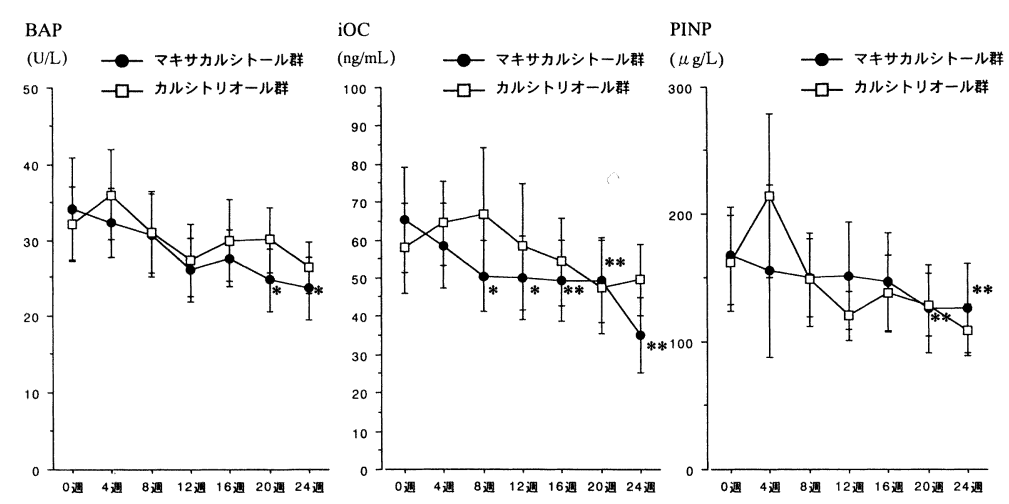

図 $3 \mathrm{BAP}$ (左), iOC (中央), $\operatorname{PINP}\left(\right.$ 右) の経過 $\left({ }^{*} \mathrm{p}<0.05,{ }^{* *} \mathrm{p}<0.01\right.$ vs. 0 週)
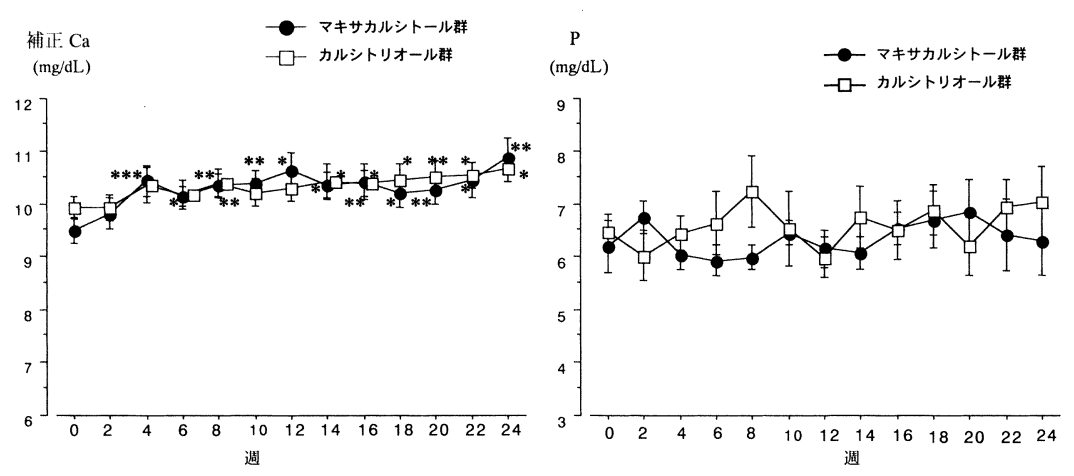

図 4 補正 $\mathrm{Ca}$ (左), $\mathrm{P}\left(\right.$ 右) の経過 $\left({ }^{*} \mathrm{p}<0.05,{ }^{* *} \mathrm{p}<0.01,{ }^{* * *} \mathrm{p}<0.001\right.$ vs. 0 週 $)$

な差を認めなかった。

以上をまとめると，マキサカルシトール群では， whole PTH, intact PTH, 7-84 PTH は全例で低下 し，24 週における低下率は各々，平均で $60.4 \pm 7.9 \%$, $58.1 \pm 7.4 \%, 51.5 \pm 7.5 \%$ あった. カルシトリオー ル群では, whole PTH, intact PTH, 7-84 PTH の低 下不良例が一時期認められたが，最終的には 24 週で 各々 $45.1 \pm 9.2 \%, 45.4 \pm 8.0 \%, 42.2 \pm 6.6 \%$ の低下を 認め, 低下率においても両群間で差を認めなかった。

\section{BAP, iOC, PINP の経過（図 3）}

BAP は, マキサカルシトール群では前值 $34.2 \pm 6.8$ U/L で, 16 週まで経過とともに低下傾向を認めたが有 意ではなく, 20 週 $24.8 \pm 4.1 \mathrm{U} / \mathrm{L}(\mathrm{p}<0.05), 24$ 週 $23.6 \pm 4.0 \mathrm{U} / \mathrm{L}(\mathrm{p}<0.05)$ と有意な低下を認めた。 力 ルシトリオール群では, 前值 $32.1 \pm 4.9 \mathrm{U} / \mathrm{L}$ で, 8 週 以降低下傾向を示したが, 有意ではなかった。

iOC は，マキサカルシトール群では前值 $65.5 \pm 13.9$ $\mathrm{ng} / \mathrm{mL}$ で, 8 週 $50.5 \pm 9.2 \mathrm{ng} / \mathrm{mL}(\mathrm{p}<0.05)$ と有意に 低下し，以後も 24 週 $35.1 \pm 9.8 \mathrm{ng} / \mathrm{mL} （ \mathrm{p}<0.01 ） ま$ で有意な低下が継続した。 カルシトリオール群では, 前值 $57.9 \pm 11.9 \mathrm{U} / \mathrm{L}$ で, 16 週以降低下傾向を示した が，有意ではなかった。

PINP は，マキサカルシトール群では前值 167.4士
$26.1 \mu \mathrm{g} / \mathrm{L}$ で，20 週 $125.4 \pm 34.1 \mu \mathrm{g} / \mathrm{L}(\mathrm{p}<0.01), 24$

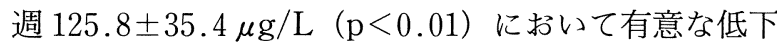
が認められた. カルシトリオール群では, 前值 $161.6 \pm$ $37.9 \mu \mathrm{g} / \mathrm{L}$ で，12 週以降低下傾向を示したが，有意で はなかった

BAP, iOC, PINP のいずれも経過中， 2 群間に有意 な差を認めなかった。

\section{3. 補正 $\mathrm{Ca}, \mathrm{P}$ の経過（図 4)}

補正 Ca は，マキサカルシトール群で前值 $9.5 \pm 0.3$ $\mathrm{mg} / \mathrm{dL}$ より, 4 週 $10.5 \pm 0.5 \mathrm{mg} / \mathrm{dL}$ と有意に上昇し $(\mathrm{p}<0.01)$, 以後も有意な高值が続き， 24 週で $10.9 \pm$ $0.3 \mathrm{mg} / \mathrm{dL}$ と有意な高值であった $(\mathrm{p}<0.01)$. カルシ トリオール群では, 前值 $9.9 \pm 0.2 \mathrm{mg} / \mathrm{dL} よ り, 8$ 週 $10.4 \pm 0.3 \mathrm{mg} / \mathrm{dL}(\mathrm{p}<0.01) ， て ゙$ 有意に上昇し，14 週 以降 24 週 $10.7 \mathrm{mg} / \mathrm{dL}(\mathrm{p}<0.05)$ まで有意な高值を示 した. 試験期間中 $11.5 \mathrm{mg} / \mathrm{dL}$ 以上の高 $\mathrm{Ca}$ 血症は, マ キサカルシトール群で 6 例, カルシトリオール群で 5 例認められた。

$\mathrm{P}$ は，マキサカルシトール群で前值 $6.2 \pm 0.5 \mathrm{mg} /$ $\mathrm{dL}$ で以後も個々の変動は大きいが，6〜 $7 \mathrm{mg} / \mathrm{dL}$ で経 過し, 有意な変動を認めなかった。 カルシトリオール 群でも前值 $6.5 \pm 0.4 \mathrm{mg} / \mathrm{dL}$ で, 以後平均值は $6 \sim 7$ $\mathrm{mg} / \mathrm{dL}$ で経過し，有意な変動を認めなかった． 


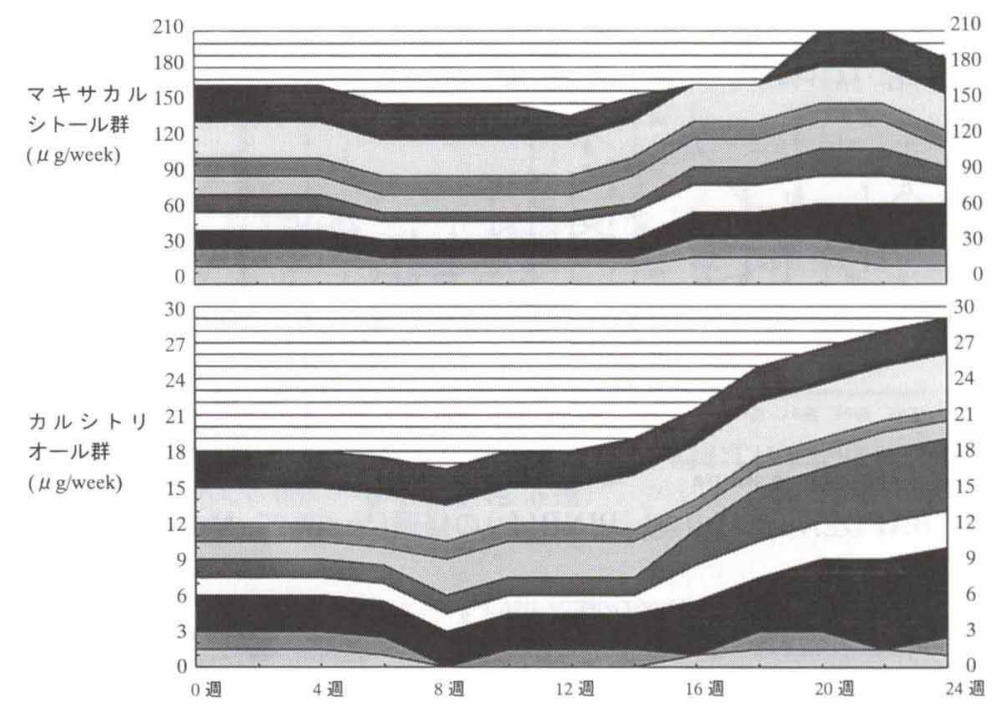

図 5 マキサカルシトールとカルシトリオールの週当たりの投与量の経過 (週当たりの投与量の経過を各症例毎に積み上げた図)

補正 $\mathrm{Ca}, \mathrm{P}$ いずれも経過中 2 群間に有意な差を認め なかった。

\section{4. 薬剤投与量の経過（図 5)}

24 週まで治療を継続したマキサカルシトール群 9 例とカルシトリオール群 9 例の 1 人 1 週あたりの薬 剂投与量の経過をみると, マキサカルシトール群では, 投与開始時平均 $18.33 \pm 2.20 \mu \mathrm{g} /$ 週で, 24 週で, $20.83 \pm 3.00 \mu \mathrm{g} /$ 週と, わずかに増量された.一方, 力 ルシトリオール群では, 投与開始時平均 $2.0 \pm 0.25$ $\mu \mathrm{g} /$ 週で, 24 週で, $3.2 \pm 0.78 \mu \mathrm{g} /$ 週と, 約 1.6 倍に増 量された。

\section{III. 考 察}

マキサカルシトールはわが国初の活性型ビタミン D 静注製剤として，2000 年より市販され，二次性副甲状 腺機能六進症への高い治療効果が期待されている。そ の特徵は, カルシトリオールの化学構造が修飾され, 血中半減期が短く, 消化管における $\mathrm{Ca}$ の吸収が比較 的少ないため, カルシトリオールに比べて血清 $\mathrm{Ca}$ 上 昇が少なく, PTHの合成・分泌を抑制することがで きる点である ${ }^{3,4)}$. また, マキサカルシトールは動物実 験において, 線維性骨炎を改善させる一方, カルシト リオールと異なり長期に投与しても低回転骨を起こさ ないことが報告されているが, その機序は不明であ る7). 線維性骨炎の改善作用はヒトにおける臨床使用 でも確認されている8).

マキサカルシトールが臨床に実際に使用され始める と, 前述した動物実験でのデータとは異なり, 高 $\mathrm{Ca}$ 血 症は高頻度で認められている. 12 か月の長期臨床試験
では, intact PTH の抑制率は $45.2 \%, 11.5 \mathrm{mg} / \mathrm{dL}$ 以 上の高 $\mathrm{Ca}$ 血症は $24.3 \%$ にられた ${ }^{9)}$. 第 3 相多施設 共同研究では, intact PTH は 40.9\%低下し, 高 Ca 血 症は $48.1 \%$ に認められた ${ }^{10)}$.また, 笠井ら ${ }^{11}$ の市販後 の多施設共同試験では, intact PTHは 4 週後に $30.3 \%$, その後 30.6 36.6\%の低下で推移した。 一回 投与量は $7.2 \pm 2.5 \mu \mathrm{g}$ よ $3.6 \pm 3.0 \mu \mathrm{g}$ へ減量さ れ, 比較的少量投与にもかかわらず, 高 $\mathrm{Ca}$ 血症は 18.5\%に認められている.

一方, 静注カルシトリオールは, 1984 年米国の Slatopolsky $ら^{12)}$ が, 難治性の二次性副甲状腺機能䒕 進症に対して使用して, 薬理学的高濃度のカルシトリ オールが血清 $\mathrm{Ca}$ 濃度上昇を介さず, 直接 $\mathrm{PTH}$ の産 生, 分泌を抑制することを報告して以来, 欧米では, 活性型ビタミン D 静注製剤のスタンダードであった。 わが国では，長らくカルシトリオールの静注製剤が認 可されなかったことより, カルシトリオールの経口間 歇大量療法（経口パルス療法）が施行され, 一定の成 績をあげてきた ${ }^{13 \sim 15)}$. しかし, 経ロパルス療法では, 高い最高血中濃度を得るためには，大量のカルシトリ オールを要し, 高 Ca 血症をきたしやすいことや, 吸収 に個人差があることなどが問題であった. 静注カルシ トリオールは, 2001 年, マキサカルシトールに続いて, わが国 2 番目の活性型ビタミン D 静注製剤として市 販された. 12 週間の前期第 2 相試験では, PTH の最終 抑制率は $39.6 \%$, 高 $\mathrm{Ca}$ 血症の発現率は $22.6 \%{ }^{16)}, 48$ 週間の長期投与試験では, PTH の最終抑制率は $52.8 \%$, 高 Ca 血症の発現率は $24.4 \%{ }^{17)}$, 52 週間の第 3 相試験では, PTH の最終抑制率は $35 \%$, 高 Ca 血症 の発現率は $13.4 \%$ であった ${ }^{18)}$. 
以上のような臨床試験から，わが国における標準的 使用量としては, マキサカルシトールの場合, PTH の 前值を基準に 5〜 10 $\mu \mathrm{g}$ を週 3 回, 静注カルシトリオー ルの場合は, 1 回 $1 \mu \mathrm{g}$ を週 $2 \sim 3$ 回とされている.

両薬剤の薬理動態に関しては，マキサカルシトール (99.4〜103.8 分) がカルシトリオール $(10.4 〜 10.9$ 時 間）に比べて短い半減期を有し，副甲状腺への分布も マキサカルシトールが投与 2 分後に速やかに分布し, 3 時間後には消失するのに対し, カルシトリオールは 3 時間後でもかなり分布しているなど違いが明らかであ る。また，マキサカルシトールおよびカルシトリオー ルの作用は核内のビタミン D レセプターを介して行 われるが，マキサカルシトールのビタミン D レセプ ターへの親和性はカルシトリオールの $1 / 8$ とされ る ${ }^{19)}$. また，ビタミン D 結合蛋白との親和性はカルシ トリオールの $1 / 580$ と少ない ${ }^{20)}$. その後, マキサカルシ トールはビタミン D レセフターとの結合にカルシト リオールとは異なる coactivator を要することが，作 用の違いに関連している可能性も示されている21)。そ して, 両薬剤の効力比は, 重松 ${ }^{22)}$ は, ビタミン Dレセ プターへの親和性の比から，1：8（マキサカルシトー ルを 1 として）と推定している.

ラットの実験では，カルシトリオールの約 7 倍の量 のマキサカルシトールを投与した場合, PTH 抑制効 果はマキサカルシトールの方が弱いという結果がでて いるが, 臨床における, マキサカルシトールと静注カ ルシトリオールの比較の検討はほとんどなかった ${ }^{23)}$.

加藤ら ${ }^{24)}$ は， PTH，年齢をマッチさせた 2 群の二次 性副甲状腺機能元進症例に，今回のわれわれの検討と 同様な量のマキサカルシトールおよび静注カルシトリ オールを投与し, 8 週間の経過を比較検討している. PTH の低下がみられた治療反応群に関しては, PTH の低下率に両薬剤で差を認めなかった。この報告の中 で，初回投与量はマキサカルシトールに関しては 5 あ るいは $10 \mu \mathrm{g}$ 週 3 回投与, 静注カルシトリオールに関 しては $1 \mu \mathrm{g}$ 週 3 回であるが, その後の投与量に関する 比較はなされていない. 一方, 藤森ら ${ }^{25)}$ は, 5 あるいは $10 \mu \mathrm{g}$ 週 3 回投与のマキサカルシトールが $2 \mu \mathrm{g}$ 週 2 回投与の経ロカルシトリオールパルス療法と血清 $\mathrm{Ca}$ および PTH 抑制に関しては同等であることを報告し ている．経過中の投与量の比較はしていないが，その デー夕を解析すると, 最終的な投与量の比は約 $4: 1$ と 推定されるが, マキサカルシトール群で 20 名中 5 例で 中止された結果, 比較的低い比率になったと考えられ る.

本研究では，製剤の容量と添付文書の用法·用量か
ら，マキサカルシトールと静注カルシトリオールの投 与量を $10: 1$ の比率で開始した. 開始当初はカルシト リオール群の方で, PTH の抑制が少なく, 血清 $\mathrm{Ca}$ 上 昇作用も少ない傾向が認められた。一方，マキサカル シトール群の方では，PTH 抑制効果は比較的速やか に発現したものの，一部の症例で高 $\mathrm{Ca}$ 血症により一 時中止を余儀なくされ，その際のリバウンドとみられ る PTH の著明な上昇が認められた，PTH，血清 $\mathrm{Ca}$ を指標に両薬剤の投与量を調節した結果, 24 週におい て, 両群ほぼ同程度の PTH 抑制, 血清 $\mathrm{Ca}$ の上昇がみ られた際の両薬剤の投与量比は約 $7: 1$ となっていた. この結果より, 両薬剤の効力比をただちに $1: 7$ (マキ サカルシトールを 1 として）と断定することは，種々 の条件をマッチングしたとはいえ，PTH のレベルに 幅のある, 異なった対象での検討であり困難であるが, ひとつの目安と考えることはできると考えられた.

今回検討した whole PTH は，従来から広く用いら れてきた intact PTH が1-84 PTH のみでなく，C 端 の巨大フラグメントである 7-84 PTH を一緒に測定 していたのに対し，1-84 PTH のみを測定する系であ る ${ }^{5,6)}$. すなわち, 従来の intact PTH は透析患者の PTH を過大評価していた可能性があり, whole PTH の方が，より正確な副甲状腺機能評価方法であるとさ れる.さらに 7-84 PTH が本来の 1-84 PTH の作用を 阻害することが明らかにされ，1-84 PTHと 7-84 PTH の比が無形成骨症を呈する透析患者では 1.0 以 下と 7-84 PTH が相対的に増加していることが示さ れ，腎性骨症における臨床的意義が注目された ${ }^{26,27)}$. し かし，その後，この比が低回転骨と高回転骨で差がな いと否定する報告もある ${ }^{28)}$ ，注意しなくてはならない 点はこれらの報告はいずれも，ビタミン D 治療をうけ ていない患者が対象であることである。ビタミン D 製 剤を投与中の症例を含んだ長期透析患者のワンポイン トの測定では, この比が 1 以下の症例は 99 例中わずか に 1 例のみとする報告がある ${ }^{29)}$.

ビタミン D 治療が 1-84 PTH, 7-84 PTH およびそ の比の動態にどういう影響を及ぼすのかについては, いままで十分検討されていない.

今回の成績では, whole PTH, intact PTH の経過 はほぼ同じであり，低下率にも差を認めなかった。両 者はマキサカルシトールおよびカルシトリオール投与 後も含め全経過を通じて,相関係数は 0.98 と相関性が 非常に高く，薬剤別，期間別で検討しても，相関係数 は 0.95 以上と高值を認め, whole PTH は intact PTH の約 6 割を示した。また，7-84 PTH はマキサカルシ トール群, カルシトリオール群いずれにおいても, 
whole PTH とほぼ同様な経過を示し, 低下した. CAP (1-84 PTH)/CIP (7-84 PTH) 比はマキサカルシトー ル投与では 24 週で, 静注カルシトリオール投与では, 4 週で有意な低下が認められたが, 両群間に有意な差 を認めなかった。この比は骨代謝回転を反映し, Monier-Faugere ら ${ }^{27}$ は Ca 負荷により, 低下が引き 起こされることを動物実験で示したが，今回の研究で は, Ca の経過と CAP (1-84 PTH)/CIP (7-84 PTH) 比の経過は一致せず，また，この比の低下の程度は少 なく，その原因や臨床的意義については不明で，今後 の検討を要する. 以上のことょり, whole PTH は真の PTH を反映するという意味では, 有意義な測定法と 考えられたが, 治療効果を観察する上では, intact PTH に優る独自の測定意義は明らかではなかった。

今回は PTH のほかに, 骨形成マーカーとして, BAP, iOC, PINP の経過を両薬剤で比較した。これら の骨形成マーカーはPTH とほほ同様の経過を示した が，カルシトリオール群では有意な低下を示さなかっ た。この原因としては, ひとつは, 骨への直接作用に 若干の差がある可能性, すなわち, マキサカルシトー ルの方が，骨代謝回転をより強く抑制する可能性が考 えられる。もうひとつは，カルシトリオールで，当初 設定した $10 ： 1$ の作用比が過大評価されたため, PTH 抑制作用がマキサカルシトールよりも弱く, 遅れて用 量を増加して, PTH に対しては同程度に抑制したの に対し, 骨代謝回転の抑制には時間がかかるために, 骨代謝マーカー低下作用が遅れた可能性が考えられ た。これらのマーカーのうち PINP は比較的新しい骨 形成マーカーで，骨が形成される際に骨芽細胞より分 泌される I 型プロコラーダンの $\mathrm{N}$ 末端と $\mathrm{C}$ 末端が切 断されてコラーゲンとなるが，その時，血中に放出さ れた I 型プロコラーゲンの $\mathrm{N}$ 末端であり, 骨粗鬆症の 経過をみる上では, 他の骨形成マーカーよりも早期に 変動するといわれている ${ }^{30}$. 今回の検討では, 他の骨形 成マーカーの経過との違いを明らかにすることはでき なかった。

今回のわれわれの研究より，マキサカルシトールと 静注カルシトリオールの効力比は $1: 7$ 程度であり, 投 与量を効力比の逆の約 $7: 1$ 亿調節すると, 同等の PTH 抑制効果が期待できることが推察された。 そし て, 1-84 PTH, 7-84 PTH, CAP/CIP 比に対する影響 もこの投与量の比率で同等であった. また, 血清 $\mathrm{Ca}, \mathrm{P}$, への影響もこの比率で差を認めなかった。骨形成マー カーへの影響には若干, 差がある可能性が示唆された が，骨自体への作用にこの両剤で差があるのかどうか は, 今回の研究では明らかでなく, 今後の課題と考元
られた。

\section{文献}

1) Martin KJ, Gonzalez EA : Strategies to minimize bone disease in renal failure. Am J Kidney Dis 38 : 1430-1436, 2001

2) Malluche HH, Mawad H, Koszewski NJ : Update on vitamin $\mathrm{D}$ and its newer analogues : Actions and rationale for treatment in chronic renal failure. Kidney Int $62: 367-374,2002$

3) Brown AJ, Ritter CR, Finch JL, Morrissey J, Martin KJ, Murayama E, Nishii Y, Slatopolsky E: The noncalcemic analogue of vitamin D, 22-oxacalcitriol, suppresses parathyroid hormone synthesis and secretion. J Clin Invest $84:$ 728-732, 1989

4) Finch JL, Brown AJ, Kubodera M, Nishii $Y$, Slatopolsky E : Differential effects of $1,25-(\mathrm{OH})_{2} \mathrm{D}_{3}$ and 22-oxacalcitriol on phosphate and calcium metabolism. Kidney Int $43:$ 561-566, 1993

5) John MR, Goodman WG, Gao P, Cantor TL, Salusky IB, Juppner H : A novel immunoradiometric assay detects full-length human PTH but not amino-terminally truncated fragments: implications for PTH measurements in renal failure. J Clin Endocrinol Metab 84:4287-4290, 1999

6) Gao P, Scheibel S, D'Amour P, John MR, Rao SD, Schmidt-Gayk H, Cantor TL : Development of a novel immunoradiometric assay exclusively for biologically active whole parathyroid hormone 184: implications for improvement of accurate assessment of parathyroid function. J Bone Miner Res $16: 605-614,2001$

7) Monier-Faugere MC, Geng $Z$, Friedler RM, Qi Q, Kubodera N, Slatopolsky E, Malluche HH : 22oxacalcitriol suppresses secondary hyperparathyroidism without inducing low bone turnover in dogs with renal failure. Kidney Int $55: 821-832,1999$

8) Tsukamoto $Y$, Hanaoka M, Matsuo T, Saruta T, Nomura M, Takahashi Y : Effect of 22-oxacalcitriol on bone histology of hemodialyzed patients with severe secondary hyperparathyroidism. Am J Kidney Dis $35: 458-64,2000$

9) Akizawa T, Suzuki M, Akiba T, Nishizawa $Y$, Kurokawa $\mathrm{K}$ : Clinical effects of maxacalcitol on secondary hyperparathyroidism of uremic patients. Am J Kidney Dis 38(4 Suppl 1) : S 147-151, 2001

10）黑川 清, 秋澤忠男, 鈴木正司, 秋葉 隆, 越川昭三, 出浦照国, 平沢由平, 小椋陽介, 塚本雄介: 透析期腎 不全患者の二次性副甲状腺機能九進症に対する $22-$ oxacalcitriol (OCT) 注射剂の安全性抢よび有効性の 検討一第 3 相一般臨床試験。腎と透析 $48: 875-897$, 2000

11）笠井健司, 阿部良悦, 若林正則, 中村一賀, 澤谷 哲, 
若林庸道：血液透析患者の二次性副甲状腺機能元進症 治療における Maxacalcitol の有用性に関する検討. 日腎誌 4：464-470，2002

12) Slatopolsky E, Weerts C, Thielen J, Horst R, Harter $\mathrm{H}$, Martin KJ : Marked suppression of secondary hyperparathyroidism by intaravenous administration of 1,25-dihydroxy-cholecalciferol in uremic patients. J Clin Invest 78 : 1097-1102, 1984

13) Tsukamoto $Y$, Nomura $M$, Marumo $F$ : Pharmacological parathyroidectomy by oral $1,25(\mathrm{OH})_{2}$ $\mathrm{D}_{3}$ pulse therapy. Nephron $51: 130-131,1989$

14) Shigematsu $T$, Kawaguchi $Y$, Unemura $S$, Yamamoto $\mathrm{H}$, Momose M, Yokoyama K, Wakabayashi Y, Ikeda M, Hasegawa T, Sakai O : Suppression of secondary hyperparathyroidism in chronic dialysis patients by single oral weekly doses of 1,25-dihydroxycholecalciferol. Intern Med 32 : 695-701, 1993

15) Akiba $T$, Ando R, Shioyama $K$, Kuriyama R, Chida $\mathrm{Y}$, Ono J, Kurihara S, Hoshino M, Togashi K, Marumo F : Intermittent high-dose oral 1,25-dihydroxyvitamin D for secondary hyperparathyroidism in hemodialysis patients. J Bone Mineral Metabolism $9: 287-294,1991$

16）越川昭三, 尾形悦郎, 黒川 清, 丸茂文昭, 酒井 紀, 荒川正昭, 森井浩世, 清野佳紀, 秋澤忠男, 秋葉 隆, 塚本雄介, 鈴木正司: 二次性副甲状腺機能六進症に対 するRo21-5535 (calcitriol) 注射剂の臨床効果一多施 設共同前期第 2 相臨床試験一, 腎と透析 $46: 415-435$, 1999

17）越川昭三, 秋澤忠男, 尾形悦郎, 黒川 清, 丸茂文昭, 秋葉 隆, 酒井 紀, 塚本雄介, 荒川正昭, 鈴木正司, 森井浩世, 清野佳紀, 大橋靖雄：透析期腎不全患者に 合併した二次性副甲状腺機能元進症に対する calcitriol 注射剂（Ro21-5535）の長期投与による臨床効 果. 腎と透析 $46 ： 123-144,1999$

18）越川昭三, 尾形悦郎, 黑川 清, 丸茂文昭, 酒井 紀, 荒川正昭, 森井浩世, 清野佳紀, 秋澤忠男, 秋葉 隆, 塚本雄介, 鈴木正司, 大橋靖雄 : 二次性副甲状腺機能 立進症に対するカルシトリオール注射剂 (Ro21-5535) の治療効果抢よび安全な使用方法に関する検討一多施 設共同第 3 相臨床試験。腎と透析 48：723-740，2000

19) Denda M, Finch J, Brown AJ, Nishii Y, Kubodera $\mathrm{N}$, Slatopolsky E : 1,25-dihydroxyvitamin $\mathrm{D}_{3}$ and 22 -oxacalcitriol prevent the decrease in vitamin $\mathrm{D}$ receptor content in the parathyroid glands of uremic rats. Kidney Int 50 : 34-39, 1996

20) Ichikawa F, Hirata M, Endo K, Katsumata K, Ohkawa H, Kubodera N, Fukagawa M, Kurokawa $\mathrm{K}$ : Attenuated up-regulation of vitamin $\mathrm{D}$-dependent calcium-binding protein by 22 -oxa-1,25-dihy- droxyvitamin $\mathrm{D}_{3}$ in uremic rats. A possible mechanism for less-calcemic action. Nephrology 4 : 391395, 1998

21) Takeyama K, Masuhiro $Y$, Fuse $H$, Endoh $H$, Murayama A, Kitanaka S, Suzawa M, Yanagisawa J, Kato S : Selective interaction of vitamin D receptor with transcriptional coactivators by a vitamin D analog. Mol Cell Biol 19 : 1049-1055, 1999

22）重松 隆：ビタミン D 静注療法における calcitriol と maxacalcitol (22-oxacalcitriol：OCT) の差異の考 察. 第 13 回腎とビタミン D 研究会記録集, p 103-105, 2002

23) Kubrusly M, Gagne ER, Urena $P$, Hanrotel C, Chabanis S, Lacour B, Drueke TB : Effect of 22oxa-calcitriol on calcium metabolism in rats with severe secondary hyperparathyroidism. Kidney Int $44: 551-556,1993$

24）加藤 仁, 松村 治, 吉川 賢, 佐藤雅男, 林 千絵, 松田昭彦, 御手洗哲也, 竹内 誠：二次性副甲状腺機 能え進症 (2 HPT) に対する静注ビタミン D 製剤の効 果. 第 13 回腎とビタミン D 研究会記録集, p 70-72, 2002

25）藤森 明, 内藤秀宗, 依藤正彦, 吾妻眞幸, 宮崎哲夫： 副甲状腺ホルモン抑制効果に関してマキサカルシトー ル静注治療はカルシトリオール経ロパルス治療と同等 である。透析会誌 $35 ： 185-189,2002$

26) Slatopolsky E, Finch J, Clay P, Martin D, Sicard G, Singer G, Gao P, Cantor T, Dusso A : A novel mechanism for skeletal resistance in uremia. Kidney Int 58:753-761, 2000

27) Monier-Faugere MC, Geng $Z$, Mawad H, Friedler RM, Gao P, Cantor TL, Malluche HH : Improved assessment of bone turnover by the PTH-(1-84)/ large C-PTH fragments ratio in ESRD patients. Kidney Int $60: 1460-1468,2001$

28) Coen G, Bonucci E, Ballanti P, Balducci A, Calabria S, Nicolai GA, Fischer MS, Lifrieri F, Manni M, Morosetti M, Moscaritolo E, Sardella D : PTH 1-84 and PTH "7-84" in the noninvasive diagnosis of renal bone disease. Am J Kidney Dis $40: 348-354$, 2002

29) Nakanishi S, Kazama JJ, Shigematsu T, Iwasaki Y, Cantor TL, Kurosawa T, Fukagawa M : Comparison of intact PTH assay and whole PTH assay in long-term dialysis patients. Am J Kidney Dis 38 (Suppl 1) : s 172-s 174, 2001

30) Garnero P, Sornay-Rendu E, Duboeuf F, Delmas PD : Markers of bone turnover predict postmenopausal forearm bone loss over 4 years. J Bone Miner Res 14 : 1614-1621, 1999 